\title{
Effects of Vocal Rehearsal and Auditory Input Enhancement on Delayed Nonword Repetition Performance in Children with and without Speech Sound Disorders
}

\author{
Mi-Jin Kima, Ji-Wan $\mathrm{Ha}^{\mathrm{b}}$ \\ ${ }^{a}$ Department of Rehabilitation Science, Graduate School of Daegu University, Gyeongsan, Korea \\ ${ }^{b}$ Department of Speech Pathology, Daegu University, Gyeongsan, Korea
}

Correspondence: Ji-Wan $\mathrm{Ha}, \mathrm{PhD}$

Department of Speech Pathology, Daegu

University, 201 Daegudae-ro, Jillyang-eup,

Gyeongsan 38453, Korea

Tel: $+82-53-850-4327$

Fax: +82-53-850-4329

E-mail: jw-ha@daegu.ac.kr

Received: January 20, 2019

Revised: February 28, 2019

Accepted: March 16, 2019

This work was supported by the National Research Foundation of Korea Grant Funded by the Korean Government (NRF-2017R1C1B1010913).

This research was supported by the Daegu University Research Scholarship Grants.
Objectives: The purpose of this study was to investigate the effects of two memory strategies, vocal rehearsal and auditory input enhancement, on phonological memory tasks in children with and without speech sound disorders. Methods: Eighteen children with speech sound disorders (pure SSD group), 8 children with speech sound disorders and comorbid language disorders (SSD+LD group), and 19 typically developing peers (TD group) aged 3 to 5 years old participated in this study. They performed delayed nonword repetition tasks according to vocal rehearsal, auditory input enhancement, and rehearsal inhibition. The nonword repetition scores, the percentage of error types, and the variability of vocal rehearsal were compared among the three groups. Results: In rehearsal inhibition, there was no significant difference among groups. However, the performances of the pure SSD group and the TD group improved in the vocal rehearsal and auditory input enhancement conditions, showing a significant difference from the SSD+LD group. As a result of the error analysis, the SSD+LD group showed significantly more 'no response' errors than the other groups, whereas the TD group showed significantly more 'phoneme substitution' errors than the other groups. The SSD+LD group showed significantly more variability in the vocal rehearsals than the other groups. Conclusion: Both vocal rehearsal and auditory input enhancement are effective for phonological memory enhancement; but auditory input enhancement, a less burdensome task for children, is more effective. The pure SSD group can expect phonological memory improvement using these two strategies matching that of the TD group; however this approach has a limited effect on the SSD+LD group, so they need different strategies.

Keywords: Speech sound disorder, Delayed nonword repetition, Phonological working memory, Vocal rehearsal, Auditory input enhancement 말소리장애(speech sound disorder)는 지속적인 말명료도 저하 로 인해 구어 의사소통에 어려움을 초래하는 장애이다. 이 중 아직 원인이 밝혀지지 않은 ‘원인 모르는 말소리장애(speech sound disorder with unknown origin)'는 그 발생에 대해 한 가지 특정 원인 을 지목하기 어렵지만, 관련 있는 기저 요인(underlying factors)으 로, 말소리 지각의 문제, 구강 감각 기능의 문제, 환경적 요인, 음운
인식 또는 음운처리(phonological processing)의 결함 등이 거론되 었다(Kim \& Shin, 2015). 이 중 음운처리는 말소리 기반의 음운정 보를 사용하는 모든 인지활동을 의미하며, 광의로는 음운인식, 음 운정보 회상(retrieval of phonological form), 음운기억(phonological memory) 등을 모두 포괄한다. 그러나 대부분의 음운처리활동 에는 기본적으로 음운기억력이 뒷받침되어야 하는 만큼, 음운처리 
에 대한 많은 연구들이 음운기억에 초점을 두고 있거나 혹은 이를 직접 다루지 않더라도 과제수행을 위해 음운기억이 요구되는 경우 가 많다. 음운기억이란 청각적으로 입력된 음운정보를 기억저장소 에 유지하고 저장하는 능력으로, 음운단기기억(phonological shortterm memory)과 음운작업기억(phonological working memory) 으로 구분할 수 있다. 경우에 따라 음운단기기억이 음운작업기억 의 하위요소로 정의되기도 하는데, Baddeley (1986)의 작업기억모 델이 그러하다. Baddeley (1986)는 음운작업기억을 말소리와 관련 된 자극을 저장하고 조작하는 것이라 정의하였고, 이에 대해 음운 저장소(phonological input store)와 시연(rehearsal)의 하위 구성요 소를 제안하였다. 음운저장소는 청각적으로 제시된 음운정보를 몇 초간 보유하는 공간으로 이는 음운단기기억에 해당한다. 반면 시연 은 보유한 음운정보를 보다 오래 유지하기 위해 소리 내지 않고 그 정보를 되뇌이는 활동으로 이는 음운작업기억과 관련 있다. 시연 을 통해 정보가 재활성화되지 않으면 음운단기기억에 일시적으로 저장된 정보는 몇 초 후사라지게 된다. 따라서 처음 접한 모든 음운 정보들은 음운단기기억을 발판으로 음운작업기억을 활용하여야 만 장기기억 속에 저장될 수 있다. 이와 관련하여 원인 모르는 말소 리장애 아동은 음운단기기억과 음운작업기억 모두에 어려움을 보 이지만, 이들의 말소리 문제를 지속시키는 요인으로 음운단기기억 보다 음운작업기억이 거론된 바 있다(Lee \& Ha, 2018).

음운기억은 숫자, 단어, 문장, 비단어 따라말하기 방법으로 측정 될 수 있다(Cho \& Seo, 2004). 그러나 숫자, 단어, 문장 따라말하기 의 경우 대상자가 기존에 가지고 있는 어휘지식의 영향을 배제할 수 없기 때문에, 음운기억 자체를 가장 민감하게 측정할 수 있는 과 제로 비단어 따라말하기가 폭 넓게 사용되고 있다(Baddeley, Gathercole, \& Papagno, 1998). 비단어 따라말하기는 청각적으로 제시 된 비단어를 듣고 바로 따라말하는 즉각 따라말하기 과제(immediate repetition task)와 일정 시간 경과 후 따라말하는 지연 따라 말하기 과제(delayed repetition task)로 구분할 수 있는데, 전자는 음운단기기억에, 후자는 음운작업기억에 보다 가깝다. 즉각 과제 에 비해 지연 과제는 난이도가 높아 일반아동뿐 아니라 성인도 성 공적인 수행을 위해 별도의 노력이 필요하다(Lee, Ha, Koo, Hwang, \& Pyun, 2016). 일상생활에서 새로운 어휘를 접하게 될 때 오랜 시 간이 경과한 후에도 그 음운정보는 그대로 정확히 기억되어야 하기 때문에, 지연 비단어 따라말하기 능력이 어휘습득, 언어발달, 음운 산출능력과 밀접한 관련이 있다는 것은 당연한 것으로 여겨진다.

지연 비단어 따라말하기 과제를 성공적으로 수행하기 위해, 즉 실험 상황에서 청각 자극을 보다 오래 보유하기 위해 요구되는 별 도의 노력으로 시연(rehearsal), 조직화, 정교화 등이 선행연구들에
서 언급되었다. 이 중 시연이 가장 효과적인 방법으로 보고되었는 데(Brookshire, 2007), 실험 상황에서 시연은 제시된 항목을 반복 하여 능동적으로 되뇌이는 것(Moon, 1994), 음운정보를 오랫동안 유지하기 위해 즉각적, 의식적, 무의식적으로 항목들을 재생하는 활동(Lee, 2015) 등으로 정의된다. 앞에서 언급한 Baddeley (1986) 의 작업기억모델에서도 그 하위 구성요소에 시연이 포함되었다는 것을 상기하면, 음운정보의 장기적 저장에 시연이 중요한 역할을 한다는 것은 의심의 여지가 없다. 그러나 Baddeley의 작업기억모델 과 실험연구 간 그 방법에 대해서는 다소 차이를 보인다. 전자의 경 우 시연은 음운정보를 소리 내지 않고 마음속으로 되뇌이는 내현 적 활동(subvocal rehearsal)으로(Baddeley, 2000), 후자의 경우는 대부분 의식적으로 소리 내어 되뇌이는 외현적 활동(vocal rehearsal)으로 설명된다(Alt \& Spaulding, 2011). Baddeley의 작업기 억모델은 일반 성인의 정상적 기억처리기제를 다루고 있기 때문에 무의식적인 내현적 활동을 시연으로 정의하였지만(Baddeley, 1986, 2000), 실험 연구의 경우 실험방법의 용이성 또는 객관성 등을 이유 로 의식적인 외현적 시연에 주로 초점을 두고 있으며, 아동을 대상 으로 한 경우는 특히 더 그러하다(Alt \& Spaulding, 2011; Ryu \& Ha, 2016).

아동 대상 연구에서 외현적 시연과 내현적 시연의 효과는 생활 연령에 따라 차이를 보였다. 어린 아동의 경우 외현적 시연이 기억 증진에 유의하게 더 많은 도움이 되었던 반면, 학령기에 가까워지 면 두 시연 간 차이가 없어졌다(Lee et al., 2016). 아동은 나이가 들 며 외현적 시연이 기억 향상에 도움이 된다는 것을 인식하고 그 활 동에 익숙해지게 됨에 따라, 별다른 노력 없이도 무의식적으로 시 연을 사용하게 되고, 이것이 바로 내현적 시연활동으로 연결된다 (Fletcher \& Bray, 1996). 일반성인을 대상으로 한 Baddeley의 작업 기억모델에서 시연이 마음속으로 되뇌이는 무의식적 활동으로 설 명된 것도 이와 같은 맥락에서 설명될 수 있다. 그러나 의사소통장 애 아동은 연령이 높은 경우에도 외현적 시연에서조차 기억 향상 의 효과를 보지 못 하고, 시연활동 자체에서 서툰 모습으로 보이고, 시연방법을 이해했음에도 비효율적으로 사용하는 등 이들의 시연 활동에 대한 어려움을 보고한 연구들을 찾아볼수 있다(Alt \& Spaulding, 2011; Ryu \& Ha, 2016). 외현적 시연을 발판으로 내현적 시연 이 발달하고 이것이 이후 모든 무의식적 기억 활동의 근간을 이룬 다는 것(Fletcher \& Bray, 1996)을 고려할 때, 의사소통장애 아동의 외현적 시연의 어려움은 그들이 지속적으로 보이는 음운작업기억 결함의 출발점일 가능성을 생각해 볼 수 있다. 특히 음운적 측면에 어려움을 보이는 말소리장애 아동의 경우 이와 관련된 어려움, 그 로 인한 음운작업기억의 결함, 그 결과 나타나는 지속적인 말소리 
문제 등을 순차적으로 예측해 볼수 있다.

말소리장애 아동에게 시연의 어려움은 필연적인 문제인 듯하다. 그들이 외현적 시연에서부터 어려움을 보이는 것은, 이것이 보편적 으로는 내현적 시연보다 아무리 쉽다 하더라도, 음운과 조음적 측 면의 전 과정을 아우르는 활동이라는 점을 감안하면 둘 다 또는 그 중 한 단계에 결함이 있는 말소리장애 아동에게는 당연히 부담되 는 과제일 것이다. ‘무의식적', 심지어 '자동적'이라 간주되는 내현적 시연은 말소리장애 아동에게는 무의식적으로 진행될 수 없는 어려 운 활동으로, 이로 인해 이득을 얻는 것 또한 불가능할 것이다. 이 와 관련하여 말소리장애 병력이 있는 경우, 그것을 극복하였더라 도, 성인이 되어서도 시연을 활용하는 음운과제에서는 여전히 어려 움을 보이고, 따라서 이를 보상하기 위해 음운루프 외에 다른 신경 학적 메커니즘을 활용한다고 보고되기도 하였다(Tkach et al., 2011). 일반성인 또는 일반아동의 말처리과정에 대한 심리언어학적 모델 을 의사소통장애 분야에 그대로 적용하는 것은 간혹 주의를 요하 는 일이며, 경우에 따라서는 제한적으로 적용해야 할 필요가 있다. Baddeley의 작업기억모델 또한 이 경우에 해당하는 듯하다.

이에 본 연구자들은 음운작업기억 증진, 이와 관련된 어휘습득 능력 향상 등을 위해, 말소리장애 아동에게 시연 이외에 다른 전략 을 모색할 필요가 있다고 판단하였다. 이에 대해 문헌연구를 실시 한 결과, 제 2 외국어 교육 분야에서 외국어 어휘 학습 시 입력 강화 (input enhancement)의 효과를 강조한 연구들(Smith, 1991; Wong, 2005)을 찾아볼수 있었다. 입력 강화란 듣기와 읽기 모드에서 이루 어지는 것으로, 동일한 소리정보를 반복적으로 강조하여 들려주거 나 또는 글자정보를 시각적으로 두드러지게 하여 보여주는 것을 의 미한다(Lee \& Huang, 2008). 즉, 학습자가 주의를 기울일 수 있도 록 다양한 방법으로 목표자극을 조작하여 입력하면 어휘 학습에 긍정적인 효과가 초래된다는 견해를 반영한 학습법이다. 따라서 본 연구에서는 시연활동에 대한 대안책으로, 제 2 외국어 교육의 입력 강화 방법을 활용하고자 하였다. 아동을 대상으로 한 연구인 만큼 글자보다는 소리자극에 초점을 둬야 할 것으로 판단되어, 청각적으 로 제시하는 자극의 입력 빈도를 높인 '청각적 입력 강화(auditory input enhancement)' 방법을 통해 그 효과를 시연활동과 비교해 보고자 하였다. 외국어 어휘 학습 시 시연보다 입력을 강조한 것은, 그것이 외국어인 만큼 학습자에게는 익숙하지 않은 음운조합을 기 억해야 하는 부담되는 일이며, 때문에 모국어에서처럼 자극 제시와 동시에 아무런 노력 없이 무의식적으로 되뇌이는 시연활동이 현실 적으로는 일어나기 어렵기 때문일 수 있다. 이런 측면에서 볼 때 외 국어 학습자가 가진 어려움은 말소리장애 아동의 경우와 크게 다 르지 않은 것으로 보인다.
따라서 본 연구에서는 음운 및 조음능력에 결함을 보이는 말소 리장애 아동을 대상으로, 지연 비단어 따라말하기 수행력에 대한 시연활동과 청각적 입력 강화의 효과를 비교하고자 하였다. 시연의 경우 선행연구들과 마찬가지로 실험방법의 용이성과 객관성을 위 해 외현적 시연을 사용하였다. 그뿐만 아니라 두 전략을 모두 사용 하지 못한 경우와도 수행력을 비교하기 위해, 추가적인 청각적 입력 없이, 외현 및 내현적 시연을 모두 동반하지 못하게 한, 시연 억제조 건에서도 동일한 과제를 실시하였다. 비단어 따라말하기는 자극어 의 음절길이에 따라 그 수행력이 민감하게 달라지는 만큼(Lee et al., 2016), 비단어의 음절수에도 차이를 두어 실험을 진행하였다. 이에 대해 말소리장애 아동을 다른 장애를 동반하지 않고 말소리 산출에만 결함을 보이는 순수 말소리장애(pure speech sound disorder, pure SSD)와 언어장애를 동반한 말소리장애(SSD with language disorder, SSD+LD)로 구분하여, 이들의 수행력을 또래 일반 아동(typically developing peers, TD)과 비교하였다. 이는 음운영역 에 결함을 보이는 말소리장애 아동은 언어장애를 동반할 가능성 이 높기 때문에(Kim \& Shin, 2015), 언어장애 동반 여부에 따른 집 단 간 차이를 음운결함의 가능성에 근거하여 해석하기 위함이었 다. 또한 언어장애를 동반하지 않은 pure SSD 아동의 경우 음운기 억이 TD 아동과 차이가 없는 연구(Bishop \& Adams, 1990; Catts, 1993), 혹은 TD 아동보다 떨어진다는 연구(Lee \& Ha, 2018)와 같이 상반된 결과들이 있는 만큼, 이와 같은 집단 간 차이를 살펴보는 것 이 필요할 것으로 판단되었다. 그뿐만 아니라 의사소통장애 아동 은 양적 점수뿐 아니라 반응의 질적 양상에도 $\mathrm{TD}$ 아동과 차이를 보인다는 선행연구에 근거하여(Ryu \& Ha, 2016), 지연 비단어 따라 말하기 과제에서 대상 아동들이 보인 오류반응을 유형별로 분류 하여 집단 간 차이를 알아보았다.

$\mathrm{SSD}$ 아동은 음운단기기억에도 어려움을 보이지만 음운작업기 억은 그 결함이 더욱 두드러진다는 선행연구(Lee \& Ha, 2018)와 관 련하여, 단기기억만을 요하는 자극어 제시 직후의 반응부터 작업 기억을 요하는 시간 경과 후 반응 사이에 이 같은 수행 저하를 초래 한 요인이 무엇인지 알아볼 필요가 있다. 이에 대해 본 연구에서는 $\mathrm{SSD}$ 아동이 시연 과정 중 시연반응을, 그것이 정확한 것이건 틀린 것이건 간에, 일관되게 유지하지 못할 가능성을 생각해 보았다. 즉, 음운정보를 들은 직후에는 비교적 양호하게 따라하였으나 반복시 연 동안 그 반응을 일관되지 유지하지 못하여, 결국 자극어로부터 더욱 거리가 먼 최종 반응을 산출하게 되는 경우이다. 이는 최근 $\mathrm{SSD}$ 의 특징 중 하나로 ‘변이성'이 주목받고 있는 것(Han \& $\mathrm{Ha}$, 2017)을 고려할 때 타당한 가정인 듯하다. 이에 본 연구에서는 외현 적 시연 과제 시 아동들이 보인 시연반응에 대해 변이성을 분석하 
여 집단간 비교를 실시하였다.

이상과 같은 연구의 필요성에 근거하여 본 논문에서 다루고자 한 연구질문들은 다음과 같다. 첫째, 세 집단 간(pure SSD, SSD+LD, $\mathrm{TD})$ 과제유형(외현적 시연, 청각적 입력 강화, 시연 억제) 및 음절길 이(3음절, 4음절, 5음절)에 따라 비단어 따라말하기 수행력에 유의 한 차이가 있는가? 둘째, 세 집단 간 과제유형에 따른 비단어 따라 말하기 오류유형별(무반응, 음절첨가, 음절생략, 음절대치, 음소첨 가, 음소생략, 음소대치, 기타) 오류율에 유의한 차이가 있는가? 셋 째, 세 집단 간 외현적 시연 시 시연반응의 변이성에 유의한 차이가 있는가?

\section{연구방법}

\section{연구대상}

본 연구의 대상은 3-5세 pure SSD 아동 18 명, SSD+LD 아동 8명, $\mathrm{TD}$ 아동 19 명의 총 45 명이었다. 모든 대상자는 부모 또는 교사에 의해 인지, 정서, 시각 및 청각 영역에 아무런 문제가 없고, 자폐나 $\mathrm{ADHD}$ 등 신경학적 장애 이력이 없고, 구강 구조 및 기능에 결함 이 없다고 보고된 아동들이었다. SSD 아동은 전문 언어재활사에 의해 말소리장애로 진단받은 아동들이었고, 연구자는 다음과 같 은 기준을 적용하여 해당 아동을 pure $\mathrm{SSD}$ 와 $\mathrm{SSD}+\mathrm{LD}$ 집단으로 분류하였다. pure SSD 집단의 기준은 첫째, 수용-표현어휘력검사 (Receptive \& Expressive Vocabulary Test, REVT; Kim, Hong, Kim, Jang, \& Lee, 2009)에서 수용 및 표현어휘 능력이 -1 SD 이상 일 것, 둘째, 취학전 아동의 수용언어 및 표현언어척도(Preschool Receptive-Expressive Language Scale, PRES; Kim, Sung, \& Lee, 2003)에서 통합 언어연령과 생활연령의 차이가 1 년 이내일 것, 셋 째, 우리말조음·음운평가(Urimal Test of Articulation and Phonology, U-TAP; Kim \& Shin, 2004)에서 단어 수준의 자음정확도 가 -2 SD 이하에 속할 것이었다. SSD+LD 집단의 기준은 첫째, $\mathrm{REVT}$ 에서 수용 및 표현어휘 능력이 -2 SD 이하에 속할 것, 둘째, PRES에서 통합 언어연령이 생활연령보다 1 년 이상 지체될 것, 셋 째, U-TAP에서 단어 수준에서 자음정확도가 - $2 \mathrm{SD}$ 이하에 속할 것 이었다. 그리고 TD 집단은 첫째, REVT에서 수용 및 표현어휘 능력 이 -1 SD 이상이고, 둘째, PRES에서 통합 언어연령과 생활연령의 차이가 1 년 이내에 속하고, 셋째, U-TAP에서 단어수준의 자음정확 도가 -1 SD 이상에 해당하는 아동들로 선정하였다. 그 이외에 비단 어 따라말하기가 청각 자극을 기반으로 한 과제인 만큼, 사전 검사 로 말지각검사(Kwon, 2004)를 실시하였다.

세 집단 간 생활월령과 성별에는 유의한 차이가 없었다 $(p>.05)$.
Table 1. Participants' characteristics in three groups

\begin{tabular}{|c|c|c|c|}
\hline & $\begin{array}{c}\text { Pure SSD } \\
\text { group }(N=18)\end{array}$ & $\begin{array}{l}\text { SSD+LD group } \\
\qquad(\mathrm{N}=8)\end{array}$ & $\begin{array}{l}\text { TD group } \\
(\mathrm{N}=19)\end{array}$ \\
\hline \multicolumn{4}{|l|}{ Gender } \\
\hline Male & 8 & 4 & 11 \\
\hline Female & 10 & 4 & 8 \\
\hline Chronological age (mo) & $55.83(6.2)$ & 56.50 (8.34) & $57.21(4.96)$ \\
\hline \multicolumn{4}{|l|}{ REVT (raw score) } \\
\hline Receptive vocabulary & $51.11(11.52)$ & $32.12(12.6)$ & $55.36(14.34)$ \\
\hline Expressive vocabulary & $58.44(12.09)$ & $37.87(12.24)$ & $59.31(9.48)$ \\
\hline \multicolumn{4}{|l|}{ PRES language age (mo) } \\
\hline Receptive & $56.11(8.28)$ & $41.5(9.62)$ & $54.26(8.57)$ \\
\hline Expressive & $54.94(6.98)$ & $41.87(7.95)$ & $57.00(8.45)$ \\
\hline \multicolumn{4}{|l|}{ U-TAP } \\
\hline PCC $(\%)$ & $81.23(8.4)$ & $78.19(13.78)$ & $96.51(2.82)$ \\
\hline Speech perception (raw score) & $18.05(1.79)$ & $15.87(2.23)$ & $19.21(1.22)$ \\
\hline
\end{tabular}

Values are presented as mean (SD).

Pure SSD = pure speech sound disorder; $S S D+L D=$ speech sound disorder with language disorder; $\mathrm{TD}=$ typically developing; $\mathrm{PCC}=$ percentage of consonants correct; REVT = Receptive \& Expressive Vocabulary Test (Kim, Hong, Kim, Jang, \& Lee, 2009); PRES = Preschool Receptive \& Expressive Language Scale (Kim, Sung, \& Lee, 2003); U-TAP= Urimal Test of Articulation and Phonology (Kim \& Shin, 2004).

${ }^{a}$ Consonant discrimination test (Kwon, 2004).

pure SSD 집단과 TD 집단 간 수용어휘력 및 표현어휘력, 수용언어 연령 및 표현언어연령, 말지각 능력에는 유의한 차이가 없었으나 ( $p>.05)$, 자음정확도의 차이는 유의하였다 $(p<.001)$. pure SSD 집 단과 $\mathrm{SSD}+\mathrm{LD}$ 집단 간 자음정확도에는 유의한 차이가 없었으나 ( $p>$.05), 수용어휘력 및 표현어휘력 $(p<.05)$, 수용언어연령 및 표현 언어연령 $(p<.001)$, 말지각 능력 $(p<.05)$ 의 차이는 유의하였다. SSD+ $\mathrm{LD}$ 집단과 $\mathrm{TD}$ 간 수용어휘력 $(p<.01)$ 및 표현어휘력 $(p<.001)$, 수 용언어연령 $(p<.05)$ 및 표현언어연령 $(p<.001)$, 자음정확도 $(p<.001)$, 말지각 능력 $(p<.001)$ 에 유의한 차이가 있었다. 이와 같은 세 집단 의 기본 정보를 Table 1 에 제시하였다.

\section{연구 도구}

비단어 자극어 선정

비단어 자극어 제작은 선행연구(Lee et al., 2016)를 참고하여 다 음과 같은 절차로 제작되었다. 첫째, 한글 사용빈도 분석(Kim \& Kang, 1997) 말뭉치 자료를 이용하여 우리말의 단음절을 모두 추 출하였다. 둘째, 추출한 음절 중 구체적 명사로서 의미를 가지는 단 음절 단어와 한국어에서 쓰이지 않는 비사용 음절을 제외하여 1,771 개의 음절을 재추출하였다. 셋째, 조음능력의 미성숙으로 인 한 과제 수행의 어려움을 배제하기 위해 초성이 경구개파찰음, 치 경마찰음, 유음으로 이루어진 음절은 제외하고자 하였으나, 그럴 
경우 남는 음절이 너무 제한적이어서 유음은 허용하였다. 그 결과 219 개의 단음절이 남았다. 넷째, 219 개의 단음절들을 무선적으로 조합하여 3음절, 4 음절, 5음절 자극어를 제작하였다. 이는 3음절 이상(Dollaghan \& Campbell, 1998) 5음절 이하(Hwang, 2015)에 서 대상 아동의 특성이 비단어 따라말하기 수행에 영향을 줄 수 있 다는 선행연구에 근거한 것이다. 다섯째, Dollaghan과 Campbell (1998)의 연구를 참고하여 첫 음절이 CV음절, 마지막 음절이 CVC 음절로 구성된 비단어만을 남겼다. 여섯째, 음절 조합 후 어절 위치 에 상관없이 초성이 탄설음인 비단어는 제외하고 설측음인 비단어 (예: 니덩멜렙)만을 최종적으로 허용하였다. 이렇게 하여 제작된 비 단어 자극어는 13 개의 자음 $/ / \neg /, / \pi /, / \exists /, /$ ᄃ /, /匹ᄄ/, /E/, /ㅂ/, / 삐/,

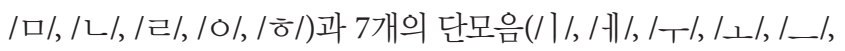
/ $/ / /$ / / / / 의 조합으로 구성되었다.

본 연구의 비단어 따라말하기 과제는 세 과제 유형(외현적 시연, 청각적 입력강화, 시연 억제) 각각이 12 개의 항목(3음절 4 개, 4 음절 4 개, 5음절 4개)으로 구성되었기 때문에, 연구에 사용된 전체 비단 어 자극어는 총 36 개였다. 한글 사용빈도 분석 말뭉치 자료(Kim \& Kang, 1997)에서 100 만 음절을 기준으로 비단어 자극어의 음절빈 도를 계산하였다. 그 결과 36 개 비단어의 음절빈도 평균은 $1,219.79$ 였다. 비단어의 단어유사성 정도를 알아보기 위해, 언어치료학과 학부생 69명을 대상으로 비단어 36개를 각각 제시한 후 각 비단어 항목이 한국어에 존재하는 실제 단어형태와 비슷한 정도를 5 점 척 도(1점 $=$ 매우 단어 같다, 5 점 =전혀 단어 같지 않다)의 평정법으로 측정하도록 하였다. 그 결과, 전체 비단어의 단어유사성 평균은 4.03 이었다. 따라서 본 연구에서 사용한 비단어는 평균적으로 음절 빈도는 높고 단어유사성은 낮은 항목들로 이루어졌음을 알 수 있 다. 이와 같은 비단어의 목록은 Appendix 1에 제시하였다.

\section{지연 비단어 따라말하기 과제 제작}

지연 비단어 따라말하기의 경우 10 초에서 30 초 정도 시간이 경 과하면 성인도 그 수행력이 급격히 저하된다는 연구결과(Brookshire, 2007)에 근거하여, 지연 시간을 10 초로 제한한 후 6세와 7세 아동 3 명을 대상으로 예비실험을 실시하였다. 제한된 지연시간 내 에 소리 내어 시연을 해야 하는 외현적 시연 과제가 실험 과제에 포 함되어 있기 때문에, 아동들이 10 초 내에 몇 회의 시연이 가능한지 파악하였다. 4 음절과 5 음절어의 경우 제한시간 내에 대략 3 회의 시 연이 가능하였고, 4 회의 시연은 경우에 따라 가능하였다. 지연시간 을 12 초로 늘려 재실험을 실시한 결과, 대상자 모두 해당 시간 내에 4 회의 시연이 가능하였다. 이러한 예비실험 결과에 근거하여, 자극 어 제시부터 12 초 경과 후 들려준 비단어를 따라말하도록 하는 과
제를 제작하도록 하였다.

36 개의 비단어를 A, B, C의 세 자극어 세트로 분류하였다. 3음 절, 4 음절, 5 음절 항목 4 개씩을 중복되지 않게 분류한 후, $\mathrm{A}$ 세트에 12 개, B세트에 12개, C세트에 12개씩 배치하였다(Appendix 1). 이 는 동일한 비단어가 하나의 과제에 반복 사용되지 않도록 하기 위 한 것으로, 대상자의 $1 / 3$ 에게는 $\mathrm{A}$ 세트, $\mathrm{B}$ 세트, $\mathrm{C}$ 세트, 또 다른 $1 / 3$ 에게는 B세트, $\mathrm{C}$ 세트, $\mathrm{A}$ 세트, 나머지 $1 / 3$ 에게는 $\mathrm{C}$ 세트, $\mathrm{A}$ 세트, $\mathrm{B}$ 세트가 각각 외현적 시연, 청각적 입력 강화, 시연 억제 조건의 자극 어로 제시되었다. 각 비단어 자극어는 전문 아나운서가 방음실에 서 녹음하였고, 실험 과제는 DmDx Display Software (Forster \& Forster, 2002)를 이용하여 전산화 과제로 제작하였다. 과제는 14 인 치 노트북을 실행시켜 실험을 진행하였다. 대상자에게 실시한 전산 화 과제는 비단어 자극어 제시 전 노트북 화면에 주의 집중을 위한 ‘+' 표시가 $500 \mathrm{~ms}$ 동안 제시되고, $500 \mathrm{~ms}$ 후 비단어가 청각적으로 제시되었다. 그러고 나서 12 초 후, "삐'라는 신호음이 나오면 대상자 들이 비단어를 산출하도록 하였다.

\section{외현적 시연 과제}

외현적 시연 과제는 녹음된 비단어를 듣고 즉각적으로 4 회의 시 연을 실시한 후, 그 비단어를 다시 말하는 과제이다. 화면에 주의 집 중을 위한 '+' 표시가 $500 \mathrm{~ms}$ 동안 나타나고 $500 \mathrm{~ms}$ 후 비단어가 청 각적으로 제시된다. 아동은 비단어를 듣고 화면에 나타나는 색깔 칸의 제시 속도에 맞춰 해당 비단어를 소리 내어 4 회 반복한다. 각 색깔 칸이 제시되는 시간 간격이 동일하기 때문에, 모든 대상자는 12 초 내에 동일한 속도로 동일한 횟수의 시연 기회를 갖게 된다. 이 후 ‘삐'하는 신호음이 나오면 아동은 바로 들었던 비단어를 또박또 박 말한다. 1,000 ms의 ITI 후 동일한 과정이 반복되고, 12 개의 비 단어는 무작위 순서로 제시된다. 앞에서 언급하였듯이 Baddeley (2000)의 작업기억모델에서 시연 과정은 소리 내지 않고 속으로 되 뇌이는 활동이지만, 어린 아동의 경우 속으로 되뇌이기에 능숙하 지 않을 뿐 아니라(Lee et al., 2016) 실험절차의 객관성을 확보하기 위해 소리 내어 되뇌이기 활동으로 실험을 진행하였다. 이와 같은 외현적 시연 조건의 과제 구성 예는 Figure 1과 같다.

\section{청각적 입력 강화 과제}

청각적 입력 강화 조건은 외현적 시연 조건과 전반적인 과제 구 성은 동일하나, 아동이 스스로 시연을 하는 대신 자극어를 4 회 더 들려주는 방식이다. 화면에 주의집중을 위한 ‘+' 표시가 $500 \mathrm{~ms}$ 동 안 나타나고 $500 \mathrm{~ms}$ 후, 비단어가 청각적으로 제시된다. 이후 동일 한 속도로 전문 아나운서가 녹음한 비단어 자극이 4 회 더 제시된 

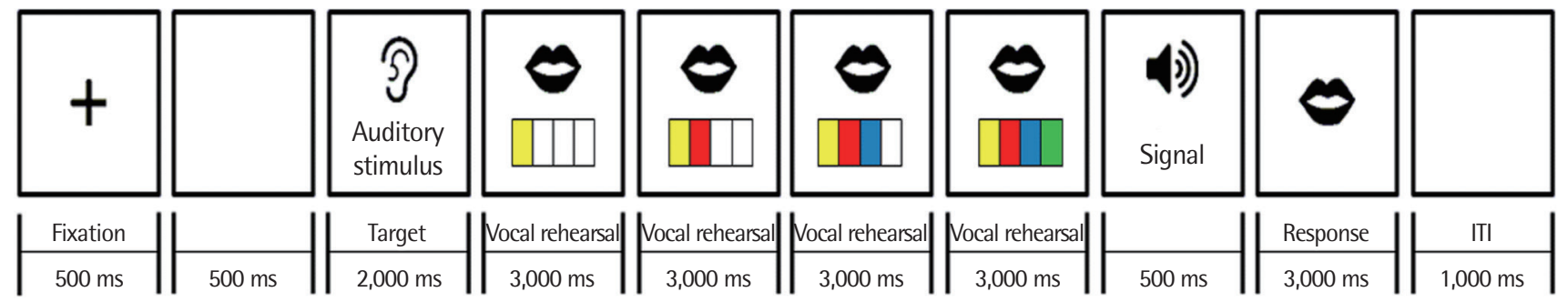

Figure 1. Delayed nonword repetition task with vocal rehearsal.

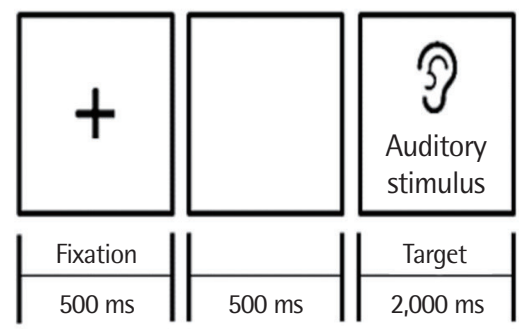

Figure 2. Delayed nonword repetition task with auditory input enhancement.
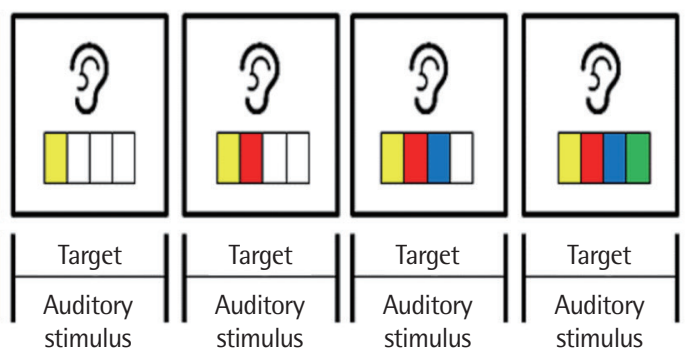

Auditory
stimulus stimulus stimulus
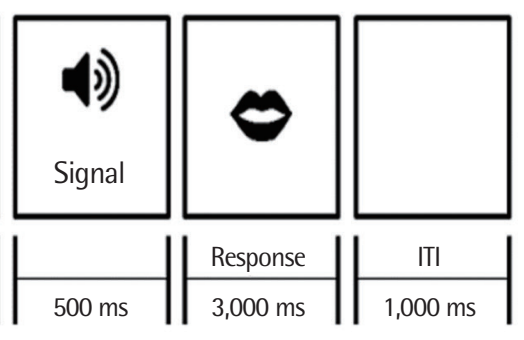
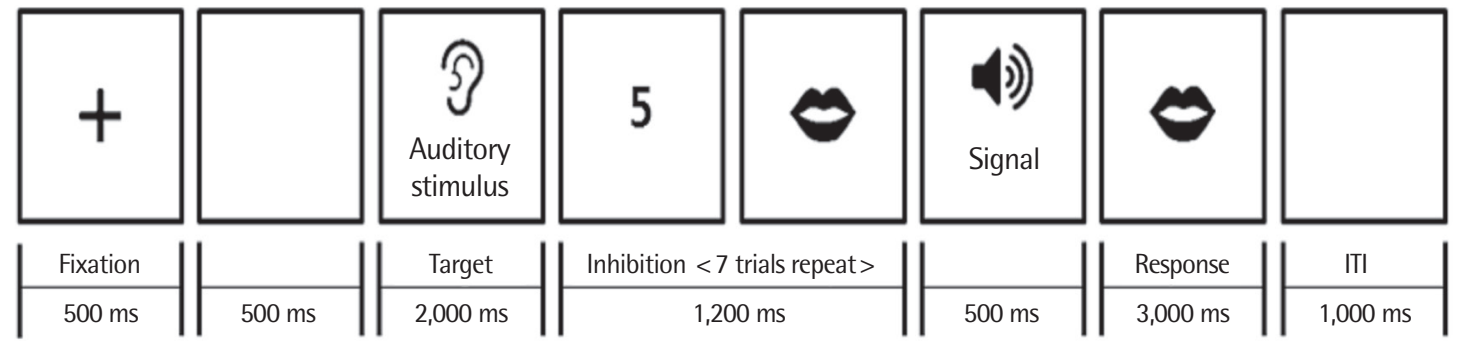

Figure 3. Delayed nonword repetition task with rehearsal inhibition.

다음, '빼' 신호음 직후 아동으로 하여금 해당 비단어를 또박또박 따라말하게 한다. 12 개의 비단어는 무작위 순서로 제시되고, 1,000 $\mathrm{ms}$ 의 ITI 후 동일 과정이 반복된다. 이와 같은 청각적 입력 강화 과 제 구성 예는 Figure 2와같다.

\section{시연 억제 과제}

시연 억제 과제는 비단어를 들고 나서 12 초의 지연시간 동안 화 면에 제시되는 7 개의 무의미한 숫자를 소리 내어 말한 후, 12 초 전 에 들었던 비단어를 기억하여 말하는 과제이다. 숫자를 말하게 하 는 것은 지연시간 동안 시연을 억제하고 주의력 분산을 막기 위한 것으로, 이 조건에서는 비단어를 보유하기 위한 어떤 도움이나 활 동도 아동에게 허용되지 않는다. 화면에 ‘' 표시가 $500 \mathrm{~ms}$ 동안 나 타나고 $500 \mathrm{~ms}$ 후 비단어가 청각적으로 제시된다. 이후 12초 동안 7 개의 숫자가 무작위로 제시되면 그것을 소리 내어 말한 다음, '삐' 신호음 직후 아동은 들었던 비단어를 말한다. 12 개의 비단어는 무
작위 순서로 제시되고, $1,000 \mathrm{~ms}$ 의 ITI 후 동일 과정이 반복된다. 이 와같은 시연 억제 과제 구성 예는 Figure 3과 같다.

\section{실험 절차}

실험은 소음이 적은 독립적인 장소를 택하여 일대일로 이루어졌 다. 사전 검사와 실험은 3 회기에 걸쳐 실시되었고, 한 회기당 40-60 분이 소요되었다. 1 회기에는 아동과 라포 형성을 한 후 REVT, U$\mathrm{TAP}$, 말지각 검사를, 2 회기에는 PRES 검사를, 3 회기에는 지연 비 단어 따라말하기 과제를 실시하였다. 지연 비단어 따라말하기 과 제는 13인치 LG 노트북(13ZD950-GX70k)으로 실시되었고 아동 과 화면은 $50 \mathrm{~cm}$ 정도 거리를 유지하여 실시되었으며, 아동이 사용 하는 헤드폰은 청력 보호를 위해 아동용 헤드폰(MOOMIN)을 사 용하였다. 모든 실험 과정을 스마트폰(iPhone 6)을 사용하여 녹음 및 녹화하였다. 


\section{자료 처리}

비단어 따라말하기의 수행력 측정

Hwang (2015)의 연구를 참고하여 정확하게 산출한 음절에 1점, 한 음소라도 오류를 보인 경우 0 점을 주었다. 예를 들어 3 음절 비단 어 /너눙닉/을 [너눈닙]이라고 산출한 경우 1점을, [너눈닉]이라고 산출한 경우 2 점을 부여하였다. 항목별 최대 점수가 자극어의 음절 길이에 따라 달라지기 때문에, 각 음절길이별 평균점수를 100 점 만 점으로 환산하여 비교하였다.

\section{비단어 따라말하기의 오류율 측정}

과제유형, 음절길이, 오류유형별로 오류를 분류할 경우 한 셀 안 에 너무 적은 수의 오류가 분포되어, 3 음절, 4 음절, 5 음절 자극어에 대한 오류를 모두 합산하여 비교하였다. 대상자들이 보인 오류유 형은 무반응, 음절첨가, 음절생략, 음절대치, 음소첨가, 음소생략, 음 소대치, 기타의 8 가지로 분류할 수 있었다. 무반응은 아동이 아무 런 반응을 하지 않거나 “모르겠어요”라고 한 경우, 기타는 자극어 와 관련이 없는 대답을 한 경우이다. 대상자마다 전체 오류수가 다 르기 때문에, 오류율 지표는 각 대상자별로 전체 오류에 대한 각 오 류유형별 비율을 구한 후 100 을 곱한 백분율로 산출하였다.

\section{외현적 시연 시 시연 반응의 변이성 측정}

변이성은 Betz와 Stoel-Gammon (2005), Han과 $\mathrm{Ha}$ (2017)의 연 구를 참고하여, 비단어의 전체 산출수 가운데 아동이 다르게 산출 한 가지수의 비율로 구한 후 100 을 곱하여 백분율로 계산하였다. 예를 들어 대상자가 /너눙닉/을 산출할 때 [너눙닉], [너눙닉], [너눈 닙], [너눙닙]으로 [너눈닙], [너눙닙]에서 한 번씩 오류를 보이고 나 머지 두 번은 정확하게 산출하였다면, 이때 대상자가 다르게 산출 한 가짓수는 [너눈닙], [너눙닙], [너눙닉]으로 3, 전체 산출 수는 4이 다. 따라서 이 경우 변이성은 $3 / 4$ 에 100 을 곱한 값이 된다.

\section{신뢰도}

비단어 따라말하기 수행력과 변이성은 그 분석방법이 까다롭지 않았으나, 오류율은 분석 시 연구자가 여러 차례 반복 측정하고 확 인하는 과정이 요구되었다. 이에 오류율에 대한 신뢰성을 확보하는 것이 필요하다고 판단되어, 전체 대상자의 $20 \%$ 인 9 명(pure SSD 3 명, $\mathrm{SSD}+\mathrm{LD} 3$ 명, TD 3명)을 대상으로 오류율에 대한 평가자 간 신뢰 도를 측정하였다. 일치한 항목수와 불일치한 항목수의 합을 일치 한 항목수로 나눈 후 100 을 곱하여 산출하였고, 그 결과 오류율에 대한 평가자간 신뢰도는 $97.2 \%$ 이었다.

\section{통계 분석}

자료의 통계처리는 SPSS version 24.0 (IBM, Armonk, NY, USA) 을 이용하여 분석하였다. 첫째, 세 집단(pure SSD vs. SSD+LD vs. $\mathrm{TD})$ 간 과제 유형(외현적 시연 vs. 청각적 입력 강화 vs. 시연 억제) 및 음절길이(3음절 vs. 4 음절 vs. 5 음절)에 따른 비단어 수행력에 유 의한 차이가 있는지 알아보기 위해, 1 피험자 간-2피험자 내 혼합설 계에 따른 반복측정분산분석(repeated measures ANOVA)을 실시 하였다. 둘째, 세 집단(pure SSD vs. SSD+LD vs. TD) 간 과제 유형 (외현적 시연 vs. 청각적 입력 강화 vs. 시연 억제) 및 오류유형(무반 응vs. 음절첨가 vs. 음절생략 vs. 음절대치vs. 음소첨가 vs. 음소생략 vs. 음소대치)에 따른 비단어 따라말하기의 오류율에 유의한 차이 가 있는지 알아보기 위해, 1피험자 간-2피험자 내 혼합설계에 따른 반복측정분산분석을 실시하였다. 셋째, 외현적 시연 과제에서 세 집단(pure SSD vs. SSD+LD vs. TD) 간 시연 반응의 변이성에 유의 한 차이가 있는지 알아보기 위해, 일원분산분석(one way ANOVA) 을 실시하였다. 반복측정분산분석 시 구형성가정이 충족되지 않을 경우, Greenhouse-Geisser의 수정된 자유도를 이용하여 결과를 해 석하였다. 피험자 간 사후검정은 Scheffe 검정을, 피험자 내 주효과 검정은 Bonferroni 검정을 실시하였다. 이요인 상호작용효과는 COMPARE 하위명령어를, 삼요인 상호작용효과는 LMATRIX \& MMATRIX 하위명령어를 입력한 syntax를 실행시켜 사후검정을 실시하였다.

\section{연구결과}

\section{세 집단 간 과제유형과 음절길이에 따른 비단어 따라말하기 수행력 비교}

세 집단 간 과제유형과 음절길이에 따른 비단어 따라말하기 수 행력에 대한 기술통계는 Table 2 와 같다. TD, pure SSD, SSD+LD 집단 순으로 수행력이 떨어졌고, 세 집단 모두 청각적 입력 강화, 외 현적 시연, 시연 억제 조건 순으로, 그리고 음절길이가 길어짐에 따 라 수행력이 저하되는 것을 알 수 있다. 이러한 차이가 통계적으로 유의한지 알아본 결과, 세 집단 간 차이 $\left(F_{(2,56)}=10.875, p<.001\right)$ 가 유의하였다. 집단 내 과제유형에 따른 주효과 $\left(F_{(1.672,170.205)}=120\right.$, $p<.001)$, 과제유형과 집단 간 상호작용효과 $\left(F_{(3.343,70.205)}=4.681\right.$, $p<.01)$, 음절길이에 따른 주효과 $\left(F_{(2,84)}=5,672.121, p<.001\right)$, 음절 길이와 집단 간 상호작용효과 $\left(F_{(4,84)}=2.821, p<.05\right)$, 과제유형과 음 절길이 간 상호작용효과 $\left(F_{(2.951,123.961)}=1,593.411, p<.001\right)$ 또한 유의 하였다. 그러나 과제유형, 음절길이 및 집단 간 삼요인 상호작용효 과는 유의하지 않았다 $\left(F_{(5.903,123.961)}=109.210, p>.05\right)$. 
Table 2. Descriptive analysis on the score of nonword repetition in three groups

\begin{tabular}{|c|c|c|c|c|}
\hline Task condition & Number of syllables & Pure SSD group $(\mathrm{N}=18)$ & $S S D+L D$ group $(N=8)$ & TD group $(\mathrm{N}=19$ ) \\
\hline \multirow[t]{3}{*}{ Vocal rehearsal } & 3 & $38.89(22.51)$ & $17.70(14.40)$ & $52.63(21.17)$ \\
\hline & 4 & $28.12(19.20)$ & $6.25(9.45)$ & 34.54 (17.72) \\
\hline & 5 & $21.94(15.07)$ & $5.00(9.63)$ & 23.68 (14.03) \\
\hline \multirow[t]{3}{*}{ Auditory input enhancement } & 3 & $49.07(21.74)$ & $32.29(24.97)$ & 62.30 (16.78) \\
\hline & 4 & $43.05(25.17)$ & $25.00(22.41)$ & $46.05(16.17)$ \\
\hline & 5 & $30.83(19.94)$ & $13.13(10.10)$ & $38.42(12.59)$ \\
\hline \multirow[t]{3}{*}{ Rehearsal inhibition } & 3 & 2.78 (6.39) & $0(0)$ & $4.82(8.92)$ \\
\hline & 4 & $4.17(6.06)$ & $0(0)$ & $4.60(8.80)$ \\
\hline & 5 & $1.11(3.66)$ & $0(0)$ & $1.32(2.81)$ \\
\hline
\end{tabular}

Values are presented as mean (SD).

Pure SSD = pure speech sound disorder; $S S D+L D=$ speech sound disorder with language disorder; $T D=$ typically developing .

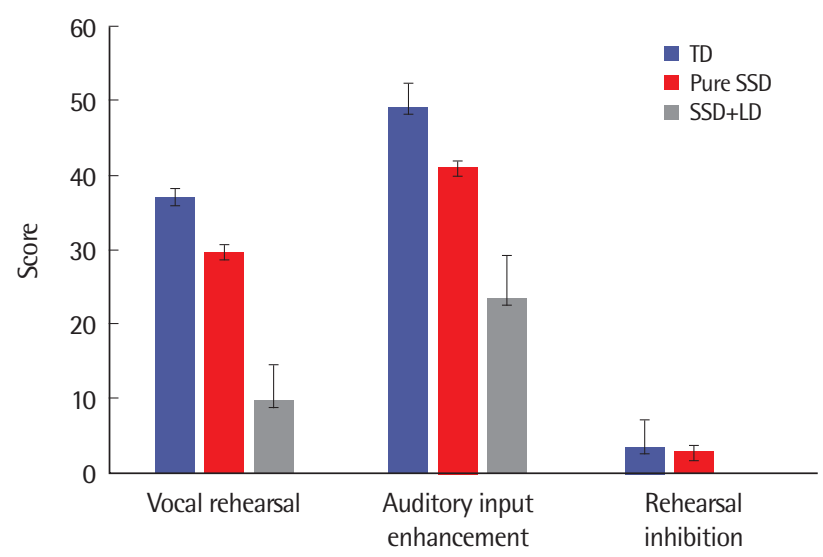

Figure 4. Nonword repetition performance according to rehearsal conditions in three groups.

Pure SSD = pure speech sound disorder; SSD+LD = speech sound disorder with language disorder; $\mathrm{TD}=$ typically developing.

집단 간 차이에 대한 사후검정 결과 $\mathrm{SSD}+\mathrm{LD}$ 집단은 $\mathrm{TD}$ 집단 $(p<.001)$ 과 pure SSD 집단 $(p<.01)$ 보다 수행력이 유의하게 떨어졌 으나,pure SSD 집단과 TD 집단간에는 유의한차이가 없었다 $(p>.05)$. 집단 내 차이에 대한 사후검정 결과 시연 억제보다 외현적 시연과 청각적 입력 강화 조건에서, 외현적 시연보다 청각적 입력 강화 조 건에서 수행력이 유의하게 좋았고 $(p<.001)$, 각 음절 간 수행력 차 이도 모두 유의하였다 $(p<.01)$. 과제유형과 집단 간 상호작용효과 에 대한 사후검정 결과, 외현적 시연과 청각적 입력 강화 조건에서 는 SSD+LD 집단의 수행력이 나머지 두 집단보다 유의하게 떨어졌 지만 $(p<.01)$, 시연 억제 조건에서는 모든 대상자들이 어려움을 보 여 집단 간 차이가 나타나지 않았다 $(p>.05$ ) (Figure 4). 음절길이와 집단 간 상호작용효과에 대한 사후검정 결과, 3 음절의 경우 pure $\mathrm{SSD}$ 집단은 $\mathrm{TD}$ 집단보다 $(p<.01), \mathrm{SSD}+\mathrm{LD}$ 집단은 $\mathrm{TD}$ 집단 $(p<.001)$ 과 pure SSD 집단보다 $(p<.01)$ 수행력이 유의하게 떨어졌다. 4 음절
과 5 음절에서는 $\mathrm{SSD}+\mathrm{LD}$ 집단은 $\mathrm{TD}$ 집단 $(p<.001)$ 과 pure $\mathrm{SSD}$ 집 단보다 $(p<.01)$ 수행력이 유의하게 떨어졌으나, pure SSD 집단은 $\mathrm{TD}$ 집단과 수행력에 차이를 보이지 않았다 $(p>.05)$. 마지막으로 과 제유형과 음절길이의 상호작용효과에 대한 사후검정 결과, 외현적 시연 조건과 청각적 입력 조건의 경우 3 음절은 4 음절 및 5 음절보다 ( $p<.001), 4$ 음절은 5 음절 $(p<.001)$ 보다 수행력이 유의하게 좋았으 나, 시연 억제 조건에서는 음절 간차이가 유의하지 않았다 $(p>.05)$.

\section{집단 간 과제유형에 따른 비단어 따라말하기 오류유형별 오류율 비교}

세 집단의 과제유형에 따른 오류유형별 오류율에 대한 기술통계 는 Table 3과 같다. 이에 대한 통계분석 결과, 오류유형에 대한 주효 과가 유의하였고 $\left(F_{(2.373,99.682)}=199.466, p<.001\right)$, 오류유형과 집단 간 상호작용효과 $\left(F_{(4.747,99.682)}=35.783, p<.001\right)$ 가 유의하였다. 또한 과제유형과 오류유형 간상호작용효과 $\left(F_{(3.691,155.009)}=102.619, p<.001\right)$ 와 과제유형, 오류유형, 집단 간 삼요인 상호작용효과 $\left(F_{(28,155.009)}=\right.$ $36.359, p<.001)$ 도 유의하였다.

오류유형의 주효과에 대한 사후검정 결과 집단에 상관없이 음소 대치는 나머지 오류유형들보다 유의하게 많이 발생하였다 $(p<.001)$. 오류유형과 집단 간 상호작용효과에 대해서는 무반응의 경우 SSD+ $\mathrm{LD}$, pure SSD, TD 집단 순으로, 음소대치의 경우 $\mathrm{TD}$, pure $\mathrm{SSD}$, $\mathrm{SSD}+\mathrm{LD}$ 집단 순으로 유의하게 많이 발생하여 $(p<.001)$, 무반응과 음소대치에 대한 집단 간 양상이 반대임을 알 수 있다(Figure 5).

과제유형과 오류유형 간 상호작용효과에 대한 사후검정 결과, 무반응은 청각적 입력 강화보다 외현적 시연에서, 외현적 시연보다 시연 억제 조건에서 유의하게 많이 발생하였다 $(p<.001)$. 반면 음소 대치는 시연 억제보다 외현적 시연에서, 외현적 시연보다 청각적 입 력 강화 조건에서 유의하게 많았다 $(p<.001)$. 그리고 음소첨가와 
Table 3. Descriptive analysis on proportion of nonword repetition errors (\%)

\begin{tabular}{|c|c|c|c|c|c|c|c|c|c|}
\hline \multirow{2}{*}{ Task condition } & \multirow{2}{*}{ Group } & \multirow{2}{*}{$\begin{array}{l}\text { No } \\
\text { response }\end{array}$} & \multicolumn{3}{|c|}{ Syllable } & \multicolumn{3}{|c|}{ Phoneme } & \multirow{2}{*}{ Others } \\
\hline & & & Addition & Omission & Substitution & Addition & Omission & Substitution & \\
\hline \multirow[t]{3}{*}{ Vocal rehearsal } & Pure SSD & $3.54(5.18)$ & $1.19(2.16)$ & $4.23(8.33)$ & $12.87(8.56)$ & $3.89(3.30)$ & $20.73(11.20)$ & 53.55 (17.64) & $0.00(0.00)$ \\
\hline & $S S D+L D$ & 26.88 (30.62) & 2.68 (3.56) & 2.81 (6.61) & $11.02(7.81)$ & $2.48(3.56)$ & $15.10(9.13)$ & $35.67(24.40)$ & $3.35(6.93)$ \\
\hline & TD & $2.11(2.3)$ & $1.00(1.47)$ & $4.00(7.62)$ & 9.54 (6.37) & $4.26(3.12)$ & $19.92(8.52)$ & 59.14 (14.32) & $0.00(0.00)$ \\
\hline \multirow{3}{*}{$\begin{array}{l}\text { Auditory input } \\
\text { enhancement }\end{array}$} & Pure SSD & $0.35(0.80)$ & $8.70(6.80)$ & $0.60(2.56)$ & $8.70(6.80)$ & $4.73(3.65)$ & $23.63(11.23)$ & $61.64(11.33)$ & $0.00(0.00)$ \\
\hline & $S S D+L D$ & 10.97 (23.98) & 4.04 (5.49) & 4.04 (5.48) & $11.20(11.07)$ & 3.27 (3.43) & $19.70(11.67)$ & $47.93(28.60)$ & $1.92(5.43)$ \\
\hline & TD & $0.16(0.69)$ & $6.25(5.51)$ & $0.58(1.45)$ & $6.25(5.51)$ & $3.36(3.50)$ & $19.70(8.80)$ & 69.64 (9.58) & $0.00(0.00)$ \\
\hline \multirow{3}{*}{$\begin{array}{l}\text { Rehearsal } \\
\text { inhibition }\end{array}$} & Pure SSD & $76.85(30.40)$ & 0.46 (1.39) & $1.91(4.01)$ & $4.28(6.23)$ & $0.21(0.87)$ & $5.85(9.90)$ & 7.66 (14.52) & 2.78 (11.79) \\
\hline & $S S D+L D$ & $96.67(9.43)$ & $0.00(0.00)$ & $0.00(0.00)$ & $0.00(0.00)$ & $0.00(0.00)$ & $0.00(0.00)$ & $0.00(0.00)$ & $0.00(0.00)$ \\
\hline & TD & $0.16(0.69)$ & $0.00(0.00)$ & $0.57(1.45)$ & $6.25(5.51)$ & $3.35(3.50)$ & $19.70(8.80)$ & 69.94 (9.58) & $0.00(0.00)$ \\
\hline
\end{tabular}

Values are presented as mean (SD).

Pure SSD = pure speech sound disorder; $S S D+L D=$ speech sound disorder with language disorder; $T D=$ typically developing.

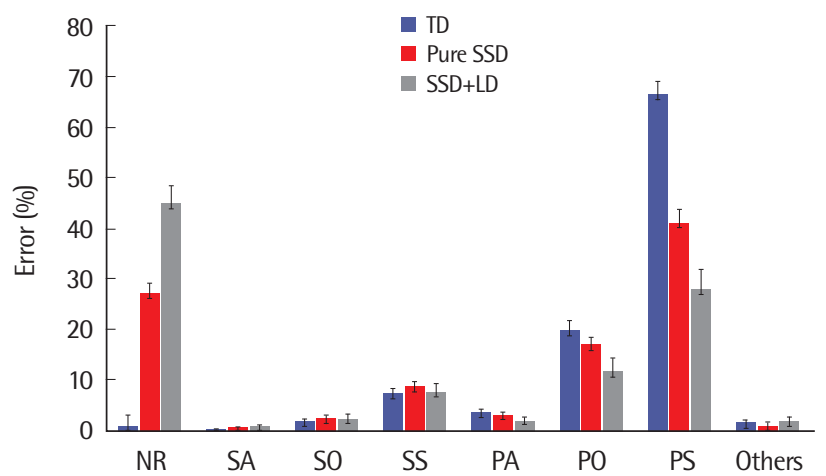

Figure 5. Percentage of error types in three groups.

Pure SSD = pure speech sound disorder; $S S D+L D=$ speech sound disorder with language disorder; $\mathrm{TD}=$ typically developing; $\mathrm{NR}=$ no response; $\mathrm{SA}=$ syllable addition; $\mathrm{SO}=$ syllable omission; $\mathrm{SS}=$ syllable substitution; $\mathrm{PA}=$ phoneme addition; $\mathrm{PO}=$ phoneme omission; $\mathrm{PS}=$ phoneme substitution.

음소생략은 시연 억제보다 외현적 시연과 청각적 입력 강화 조건에 서 유의하게 많았다 $(p<.001)$. 과제유형, 오류유형, 집단 간 삼요인 상호작용효과에 대한 사후검정 결과, 외현적 시연 조건에서 무반 응은 pure SSD와 TD 집단보다 SSD+LD 집단에서 많이 나타난 반 면 $(p<.001)$, 음소대치는 $\mathrm{SSD}+\mathrm{LD}$ 집단보다 TD 집단에서 유의하 게 많이 발생하였다 $(p<.001)$. 청각적 입력 강화 조건에서는 음소대 치가 pure $\mathrm{SSD}$ 와 $\mathrm{SSD}+\mathrm{LD}$ 집단에 비해 $\mathrm{TD}$ 집단에서 유의하게 많 이 나타났다 $(p<.001)$. 마지막으로 시연 억제 조건에서 무반응은 $\mathrm{TD}$ 집단에 비해 pure $\mathrm{SSD}$ 와 $\mathrm{SSD}+\mathrm{LD}$ 집단에서 유의하게 많았고 ( $p<.001)$, 음소첨가, 음소생략 및 음소대치는 pure SSD와 SSD+LD 집단보다 TD 집단에서 유의하게 많이 발생하였다 $(p<.001)$.

\section{세 집단 간 시연 반응의 변이성 비교}

외현적 시연 조건의 시연 반응 동안 대상자들이 보인 변이성에
Table 4. Descriptive analysis on proportion of variability in vocal rehearsals

\begin{tabular}{lccc}
\hline & $\begin{array}{c}\text { Pure SSD group } \\
(\mathrm{N}=18)\end{array}$ & $\begin{array}{c}S S D+L D \text { group } \\
(\mathrm{N}=8)\end{array}$ & $\begin{array}{c}\text { TD group } \\
(\mathrm{N}=19)\end{array}$ \\
\hline Variability in vocal rehearsal & $57.08(10.91)$ & $71.56(11.12)$ & $49.21(9.08)$ \\
\hline
\end{tabular}

Values are presented as mean (SD).

Pure SSD = pure speech sound disorder; SSD+LD = speech sound disorder with language disorder; $\mathrm{TD}=$ typically developing.

대한 기술통계는 Table 4 와 같다. 통계분석 결과, 세 집단 간 시연 반 응 변이성에 유의한 차이가 있었다 $(p<.001)$. 사후검정 결과, pure $\mathrm{SSD}$ 와 TD 집단보다 $\mathrm{SSD}+\mathrm{LD}$ 집단에서 변이성이 유의하게 높았고 $(p<.01)$, pure SSD와 TD 집단 간에는 그 차이가 유의하지 않았다 $(p>.05)$.

\section{논의 및 결론}

본 연구에서는 pure SSD 집단, $\mathrm{SSD}+\mathrm{LD}$ 집단, $\mathrm{TD}$ 집단 간 과제 유형과 음절수에 따른 지연 비단어 따라말하기 수행력, 과제유형 에 따른 오류유형별 오류율, 외현적 시연 시 시연 반응의 변이성을 비교하고, 외현적 시연과 청각적 입력 강화라는 기억 전략이 대상 자들의 음운작업기억에 미치는 영향을 알아보고자 하였다. 그 결 과 과제수행 시 집단마다 각 과제유형으로부터 얻는 이득과 오류 유형의 양상이 유의하게 달랐고, $\mathrm{SSD}+\mathrm{LD}$ 집단은 나머지 두 집단보 다 시연 반응의 변이성을 유의하게 많이 보였다. 이와 같은 결과에 대해 보다 심층적인 논의가 필요할 것이다.

우선 지연 비단어 따라말하기 과제의 수행력에 대해서는 시연 억 제 조건에서부터 논의를 시작하는 것이 좋겠다. 시연 억제 조건에 서는 지연 비단어 따라말하기에 대한 집단 간 그리고 음절수 간 어 떠한 차이도 유의하지 않았다. 서론에서 언급하였듯이 지연 비단 
어 따라말하기는 난이도가 높아 일반성인의 경우도 성공적인 수행 을 위해 별도의 노력이 필요하다(Brookshire, 2007). 음운정보를 보 다 오래 기억하기 위해 들었던 정보를 소리내어 되뇌이는 외현적 시 연이나 속으로 되뇌이는 내현적 시연 등 그 어떤 전략도 허용하지 않았던 시연 억제 조건에서는 일반아동도 다른 두 집단만큼, 그리 고 상대적으로 쉽다고 여겨졌던 3음절 비단어에서도 과제수행에 난관을 겪을 수 있음을 알 수 있다. 그러나 외현적 시연 또는 청각적 입력 강화 전략을 사용하도록 한 결과, pure SSD 집단과 TD 집단 은 수행력이 상당히 향상되어 $\mathrm{SSD}+\mathrm{LD}$ 집단과 유의한 차이를 보였 고, 집단에 상관없이 3 음절어는 4 음절어보다, 4 음절어는 5 음절어 보다 오래 기억하는 것이 더 쉬워졌다.

이때 외현적 시연과 청각적 입력 강화의 두 조건 모두에서 pure $\mathrm{SSD}$ 와 TD 집단 간 수행력에 유의한 차이가 없었다는 점에 주목할 필요가 있다. 이는 언어장애를 동반하지 않은 pure SSD 집단의 경 우, 음운작업기억의 증진에 외현적 시연과 청각적 입력 강화 둘 다 로부터 일반 아동만큼 도움을 받을 수 있음을 시사한다. 이러한 결 과는 비단어 따라말하기는 조음보다 어휘능력과 관련이 있다는 연 구(Munson, Kurtz, \& Windsor, 2005), 음운기억은 언어발달지체 동반 여부가 중요한 변수라는 연구(Bird, Bishop, \& Freeman, 1995) 와 같이, 음운작업기억을 조음보다 음운 또는 언어와 관련 지어 설 명한 선행연구들과 같은 맥락에서 해석할 수 있다. 본 연구의 pure SSD 집단은 다소 엄격한 사전검사를 통해 언어영역에는 아무런 문 제가 없다고 진단된 대상자들인 만큼, 음운적 측면보다 조음적 측 면에 본질적인 결함이 있는 대상자들로 간주할 수 있다. 본 연구 결 과로 인해 음운에 결함이 없는 pure SSD 집단의 경우에는 외현적 시연 전략이 음운정보를 오래 기억하게 하는 데에 충분한 도움을 제공할 수 있음을 알 수 있다. 이러한 결과에 근거할 때 시연 활동 은, 그것이 외현적 시연일지라도, 조음보다 음운영역과 더욱 밀접한 관련이 있는 활동으로 여겨진다.

또한 $\mathrm{SSD}+\mathrm{LD}$ 집단의 경우 청각적 입력 강화를 통해 그 수행력 이 향상되긴 하였지만(Table 2) pure SSD와 TD 집단만큼은 아니었 으며, 따라서 이 조건에서도 나머지 두 집단보다 수행력이 유의하게 떨어졌다. 이러한 결과는 이들의 사전검사 결과에서 그 실마리를 찾을 수 있을 듯하다. 연구대상자 정보에 의하면(Table 1), SSD+LD 집단은 언어 검사뿐 아니라 말지각 검사에서도 나머지 두 집단보다 유의하게 점수가 떨어졌다. 청각적 입력 강화가 청지각적 처리과정 을 기반으로 하는 과제라는 것을 감안할 때, 말지각 능력이 떨어지 는 SSD+LD 집단이 이 조건에서도 여전히 과제 수행에 어려움을 겪 었다는 것은 어쩌면 당연한 결과일 것이다. 따라서 청각적 입력 강 화 전략은 정상적인 말지각 능력을 갖추고 있는 아동일수록 더욱
유용한 방법임을 간과하지 말아야 할 것이다.

집단 및 음절수에 상관없이 단지 과제유형만을 비교하였을 때, 청각적 입력 강화는 외현적 시연보다 대상자의 전반적인 수행력을 향상시키는 데에 유의하게 도움을 주었다. 외현적 시연은 대상자가 직접 실시해야 하는 활동인 반면, 청각적 입력 강화는 다른 사람에 의해 실시되는 활동이다. 입력 자극을 집중하여 들어야 하기 때문 에 청각적 입력 강화가 아무런 부담이 없는 활동이라고는 할 수 없 지만, 다양한 정보가 아닌 동일한 자극어를 반복적으로 듣기만 하 면 되는 만큼 그리 큰 부담은 아닐 듯하다. 이런 측면에서 볼 때 대 상 아동의 특성에 상관없이 인지 및 조음적 부담이 적은 청각적 입 력 강화가 음운정보를 오래 기억하게 하는 데에 더욱 효과적인 기 억 전략이라는 연구 결과는 타당한 듯하다. 다만 시연은 혼자 스스 로 사용할 수 있는 전략인 반면, 청각적 입력 강화는 다른 사람의 도 움을 전제로 한다. 때문에 청각적 입력 강화는 그 사용에 있어 제한 적일 수 밖에 없다. 그러나 자발적 시연이 불가능하거나 시연을 비효 율적으로 사용하는 대상자의 경우, 특히 말소리산출 결함이라는 대상자의 본질적인 특성으로 인해 시연활동에 부담감이 클 수밖에 없는 말소리장애 아동의 경우, 청각적 입력 강화는 음운기억 향상 에 매우 유용한 방법일 것이다. 이것을 치료적 측면과 연관 지어 생 각해 볼 때, 본 연구 결과는 언어재활사로서 말소리장애 아동들의 음운기억 향상을 위해 일차적으로 접근해야 할 치료 방법에 대해 방향성을 제시해 준다. 즉, 치료 초기에는 대상자에게 부담이 적고 효과적인 청각적 입력 강화를 활용하고, 이후 대상자의 음운능력 향상과 함께 시연 활동을 훈련함으로써 자발적 시연 활동에 점차 익숙해지도록 하는 것이 치료 효과를 향상시킬 수 있을 것이다.

자극어의 음절수와 관련하여, 비단어 따라말하기는 음절수에 따라 대상 집단의 수행 결과가 민감하게 달라지는 과제라고 할 수 있다. 4 음절 비단어에서 의사소통장애 아동과 일반아동 간, 그리 고 연령에 따라 수행 차이가 두드러진다는 선행연구들(Hwang, 2015; Munson et al., 2005)과 달리, 본 연구에서는 3음절 비단어에 서만 세 집단 간 차이가 각각 유의하였다. 이는 과제의 난이도와 관 련하여 해석할 수 있는 부분으로, 선행연구에서 사용하였던 즉각 비단어 따라말하기와 달리 본 연구의 지연 비단어 따라말하기는 일반아동들에게도 매우 어려운 과제였다. 이로 인해, 오히려 상대 적으로 난이도가 낮은 3 음절 비단어에서 집단 간 차이가 민감하게 나타난 것으로 보인다. 본 연구의 경우 pure $\mathrm{SSD}$ 와 TD 집단을 변별 할 수 있는 과제는 3음절 과제로, 음절수가 비단어 따라말하기 수 행력에 미치는 영향은 그것이 즉각 따라말하기인지 혹은 지연 따 라말하기인지와 같은 과제의 실시방법 또는 과제의 난이도 등에 따 라 그 결과가 달라질 수 있음을 유의하여야 할 것이다. 
또한 과제유형에 대한 오류유형별 오류율을 통해 집단 간 비단 어 따라말하기 반응의 질적 차이를 확인할 수 있었다. 본 실험 과제 에서 대상자들이 보인 오류유형은 무반응, 음절첨가, 음절생략, 음 절대치, 음소첨가, 음소생략, 음소대치, 기타의 8가지로 분류할 수 있었다. 이 중 무반응은 가장 심각한 오류로, 음소대치는 가장 경미 한 오류로 간주할 수 있는데, 이 두 오류의 양상이 정반대로 정리될 수 있다는 것이 흥미롭다. 집단과 관련하여 무반응은 SSD+LD, pure SSD, TD 순으로 유의하게 많이 발생한 반면, 음소대치는 그 반대였다. 즉, 정반응 점수에서 가장 수행력이 낮았던 SSD+LD 집 단은 오반응 분석에서도 가장 심각한 오류를 많이 보였고, 상대적 으로 점수가 양호하였던 pure SSD 집단과 점수가 가장 높았던 TD 집단은 오반응에서도 심각한 오류는 줄어들고 대신 경미한 오류를 더 많이 나타내었다. 과제유형의 특성에 따라서도 일관된 양상을 관찰할 수 있었는데, 무반응은 가장 어려운 과제인 시연 억제 조건 에서, 음소대치는 상대적으로 쉬운 과제인 청각적 입력 강화 조건 에서 많이 발생하였다. 이러한 결과로 인해 정반응이 아니기 때문 에 점수에는 반영되지 않더라도 대상자의 특성과 과제 조건에 따 라 오반응의 양상은 질적으로 달라질 수 있음을 알 수 있다.

그뿐만 아니라 정반응 점수로는 알 수 없었던 집단 간 미세한 차 이가 간혹 오반응 분석에서 드러나는 경우가 있는데, 본 연구에서 오류율에 대한 집단과 오류유형의 이요인 상호작용효과, 그리고 집 단, 과제유형 및 오류유형의 삼요인 상호작용효과가 그러하다. 첫 번째 연구질문인 수행력 비교에서는 나타나지 않았던 pure SSD와 $\mathrm{TD}$ 집단 간 차이가 오류율 분석을 통해 드러났다. 즉, 오류유형 분 석 결과 pure SSD 집단은 무반응을, TD 집단은 음소대치를 유의하 게 많이 보였는데, 이는 음운기억에 대한 각 집단의 상대적인 능력 차이를 반영하는 것으로 보인다. 또한 수행력 비교 결과 시연 억제 조건에서는 세 집단 간, 그리고 청각적 입력 강화 조건에서는 pure $\mathrm{SSD}$ 와 TD 집단 간 차이가 유의하지 않았다. 그러나 오류율을 비교 한 결과 시연 억제 조건의 경우 pure $\mathrm{SSD}$ 와 $\mathrm{SSD}+\mathrm{LD}$ 집단은 $\mathrm{TD}$ 집 단보다 무반응을, 반대로 $\mathrm{TD}$ 집단은 두 집단보다 음소 차원의 오 류를 유의하게 많이 보임으로써 집단 간 차이가 비로소 드러났다. 또한 청각적 입력 강화 조건에서는 가장 경미한 오류인 음소대치의 비율이 pure SSD보다 TD 집단에서 유의하게 많이 발생함으로써, 두 집단 간 유의한 차이를 관찰할 수 있었다. 따라서 오류 분석을 통해서도 집단 간 미세한 차이와 같은 중요한 정보를 얻을 수 있음 을 간과하여서는 안 될 것이다.

마지막으로 외현적 시연 시 시연 반응 변이성은 pure SSD와 TD 집단보다 $\mathrm{SSD}+\mathrm{TD}$ 집단에서 유의하게 높았다. $\mathrm{SSD}+\mathrm{LD}$ 아동의 경 우 낮은 음운기억력으로 인해 음운저장소에 음운정보를 저장하는
데에 어려움을 겪을 뿐 아니라, 이를 보완하기 위해 전략적으로 시 연 활동을 실시하더라도 그 수행 과정에서 최초의 정보로부터 많 은 변형과 삭제 과정을 겪음으로써 오히려 더 왜곡된 정보를 보유 하게 될 가능성이 있음을 시사한다. 이러한 결과는 음운영역에 결 함이 있는 SSD+LD 아동의 경우 민첩하고 능숙한 음운처리능력이 요구되는 시연 활동에서 다양한 어려움에 처할 수 있으며, 따라서 이들의 음운작업기억 향상을 위해서는 시연 이외에 다른 방법을 반드시 강구해야 할 것임을 시사한다. 아울러 앞에서 기술하였던 청각적 입력 강화의 제한된 효과를 함께 고려해 볼 때, $\mathrm{SSD}+\mathrm{LD}$ 아 동의 입력(input) 및 출력(output) 측면의 복합적인 어려움은 음운 작업기억 결함, 새로운 어휘학습에의 어려움, 수용 및 표현언어 결 함 등 언어영역 전반에 걸친 이들의 지속적인 곤란함으로 이어질 가능성 또한 생각해 볼수 있다.

이상의 결과들을 정리해 보면 다음과 같은 결론을 얻을 수 있다. 그 어떤 전략도 취하지 않으면 제시된 음운정보를 12 초 이상 보유 하는 것은 일반 아동에게도 매우 어려운 작업이다. 그러나 외현적 시연과 청각적 입력 강화는 이를 극복하는 데에 도움이 되는 전략 이며, 특히 대상자에게 부담감이 적은 청각적 입력 강화는 더욱 효 과적이다. 그러나 언어장애를 동반한 $\mathrm{SSD}+\mathrm{LD}$ 아동의 경우 그 효 과는 제한적이다. 여러 선행연구들에서 보고된 말소리장애 아동의 음운기억 또는 비단어 따라말하기 수행력에 대한 일관되지 않은 결과는 이 집단의 이질성에 기인한 것으로 보인다. 본 연구의 경우 나름대로 엄격한 기준을 적용하여 언어장애 동반 여부에 따라 집 단을 세분화하였기 때문에, pure SSD와 SSD+LD 집단 간 유의한 차이를 관찰할 수 있었다. 본 연구의 pure SSD 집단의 수행력은 TD 집단과 전반적으로 차이가 없었으나, 그렇다고 하여 이들의 능력이 일반 아동과 동일하다는 것은 아니다. 특정 조건 또는 오류율 분석 에서 두 집단 간 차이가 드러나, 과제의 난이도에 따라 또는 보다 심 층적 분석을 적용하면 pure SSD 집단의 상대적인 미세한 결함을 관찰할 수 있음을 알 수 있었다. 이와 같은 SSD+LD와 pure SSD 집 단의 양적 및 질적 차이는, 서론에서도 언급하였듯이, 일반 성인 또 는 일반 아동의 말처리과정에 대한 심리언어학적 모델을 의사소통 장애 분야에 그대로 적용하는 것은 주의를 요한다는 보편적 진리 를 다시 한 번 상기시켜 준다. 그러나 그보다 중요한 것은 pure SSD 아동의 경우도 일반아동과 동일한 방법으로 음운기억 향상을 충 분히 유도할 수 있으며, 또한 그들에게 부담이 되지 않을까 염려되 었던 시연 활동도 그중 하나라는 것이다.

청각적 입력 강화가 아무리 효과적인 방법이라고 하더라도, 앞에 서도 언급하였듯이, 이는 다른 사람의 도움을 전제로 한다. 따라서 궁극적으로는 대상 집단에 상관없이 아동 혼자 스스로 사용할 수 
있는 시연 활동에 점차 익숙해지도록 훈련해 가는 것이 바람직할 것이다. 새로운 어휘의 습득을 위해서는 의미정보와 함께 음운정 보를 정확하게, 오래 기억하는 것이 관건이며, 이것은 언어발달의 필수적인 과정이다. 때문에 음운정보 기억을 위해 외현적 시연과 청각적 입력 강화를 둘 다 효과적으로 사용하지 못하였던 $\mathrm{SSD}+\mathrm{LD}$ 아동의 경우, 이를 보완할 수 있는 또 다른 대안책을 생각 해 보아야 할 것이다. 이를 테면 청각적 입력 강화를 더욱 두드러지 게 하는 방법, 또는 최초의 시연 반응을 정확하게 하고 그것을 시간 이 경과하여도 일관적으로 유지할 수 있도록 유도하는 방법 등을 고안하여 적용해 본 후 그 효과를 입증해 보는 추후연구가 필요할 것이다.

또한 $\mathrm{SSD}+\mathrm{LD}$ 아동들이 시연반응에서 유의하게 높은 변이성을 보인 것이 입증된 만큼, 추후 연구에서는 시연활동 시 나타난 오류 에 대해서도 심층적인 분석이 필요할 것이다. 본 연구에서는 시연 활동 자체만을 독려하였을 뿐 정확한 시연을 유도하지는 않았다. 정확하지 않은 시연은 음운정보를 유지하는 데에 오히려 방해가 될 것이며, 따라서 시연반응에 대한 세세한 오류분석, 시연의 오류 가 과제수행에 미치는 영향 등에 대해 확인해 보아야 할 것이다. 그 러나 본 연구에서 충분하지 않은 대상자 수가 연구의 가장 큰 제한 점인 만큼, 추후연구에서는 먼저 대상자 수를 더욱 확보하여 보다 신뢰로운 결과를 얻기 위한 노력이 요구된다.

\section{REFERENCES}

Alt, M., \& Spaulding, T. (2011). The effect of time on word learning: an examination of decay of the memory trace and vocal rehearsal in children with and without specific language impairment. Journal of Communication Disorders, 44(6), 640-654.

Baddeley, A. (1986). Working memory. New York, NY: Clarendon Press.

Baddeley, A. (2000). The episodic buffer: a new component of working memory? Trends in Cognitive Sciences, 4(11), 417-423.

Baddeley, A., Gathercole, S., \& Papagno, C. (1998). The phonological loop as a language learning device. Psychological Review, 105(1), 158-173.

Betz, S. K., \& Stoel-Gammon, C. (2005). Measuring articulatory error consistency in children with developmental apraxia of speech. Clinical Linguistics \& Phonetics, 19(1), 53-66.

Bird, J., Bishop, D. V., \& Freeman, N. H. (1995). Phonological awareness and literacy development in children with expressive phonological impairments. Journal of Speech, Language, and Hearing Research, 38(2), 446-462.

Bishop, D. V., \& Adams, C. (1990). A prospective study of the relationship between specific language impairment, phonological disorders and reading retardation. Journal of Child Psychology and Psychiatry, 31(7), 10271050.

Brookshire, R. H. (2007). Introduction to neurogenic communication disorders (7th ed.). St. Louis, MO: Mosby.

Catts, H. W. (1993). The relationship between speech-language impairments and reading disabilities. Journal of Speech, Language, and Hearing Research, 36(5), 948-958.

Cho, J. R., \& Seo, S. R. (2004). The relations among Korean phonological processing skills, English vocabulary knowledge, and vocabulary learning in primary school children. Foreign Languages Education, 11(1), 179-195.

Dollaghan, C., \& Campbell, T. F. (1998). Nonword repetition and child language impairment. Journal of Speech, Language, and Hearing Research, 41(5), 1136-1146.

Fletcher, K. L., \& Bray, N. W. (1996). External memory strategy use in preschool children. Merrill-Palmer Quarterl, 42(3), 379-396.

Forster, K., \& Forster, J. (2002). DMDX display software. Tucson, AZ: University of Arizona.

Han, E. J., \& Ha, J. W. (2017). Variability of speech sound production according to phonetic complexity in children with and without speech sound disorders. Communication Sciences \& Disorders, 22(4), 772-783.

Hwang, M. (2015). Nonword repetition of typically developing children. Communication Sciences \& Disorders, 20(3), 374-385.

Kim, H. K., \& Kang, B. M. (1997). Frequency analysis of the use of Hangul. Seoul: Korea University, Research Institute of Korea Studies.

Kim, S. J., \& Shin, J. Y. (2015). Speech sound disorders. Seoul: Sigma Press.

Kim, Y. T., Hong, G. H., Kim, K. H., Jang, H. S., \& Lee, J. Y. (2009). Receptive \& expressive vocabulary test (REVT). Seoul: Seoul Community Rehabilitation Center.

Kim, Y. T., \& Shin, M. J. (2004). Urimal Test of Articulation and Phonology (U-TAP). Seoul, Korea: Hakjisa

Kim, Y. T., Sung, T. J., \& Lee, Y. K. (2003). Preschool receptive-expressive language scale (PRES). Seoul: Seoul Community Rehabilitation Center.

Kwon, M. S. (2004). Evolution of aphasia profile and auditory comprehension ability in Wernicke' aphasia (Doctoral dissertation). Ewha Womans University, Seoul, Korea.

Lee, K. E., \& Ha, J. W. (2018). Phonological short-term and working memory in 5-and 6-year-old children with speech sound disorders. Communication Sciences \& Disorders, 23(3), 713-724.

Lee, S. J. (2015). A comparative study of phonological short-term memory ac- 
cording to the rehearsal conditions in 6- to 7-year-old children (Master's thesis). Daegu University, Gyeongsan, Korea.

Lee, S. J., Ha, J. W., Koo, M. M., Hwang, Y. M., \& Pyun, S. B. (2016). Delayed non-word repetition according to rehearsal conditions in 6-to 7-year-old children. Communication Sciences \& Disorders, 21(1), 69-83.

Lee, S. K., \& Huang, H. T. (2008). Visual input enhancement and grammar learning: a meta-analytic review. Studies in Second Language Acquisition, 30(3), 307-331.

Moon, S. M. (1994). Development of learning strategies and academic performance. Korean Journal of Educational Research, 32(5), 47-74.

Munson, B., Kurtz, B. A., \& Windsor, J. (2005). The influence of vocabulary size, phonotactic probability, and wordlikeness on nonword repetitions of children with and without specific language impairment. Journal of Speech,
Language, and Hearing Research, 48(5), 1033-1047.

Ryu, E. J., \& Ha, J. W. (2016). The effect of vocal rehearsal on retrieval of new phonological representations in children with and without specific language impairment. Communication Sciences \& Disorders, 21(4), 605-616.

Smith, M. S. (1991). Speaking to many minds: on the relevance of different types of language information for the L2 learner. Interlanguage Studies Bulletin (Utrecht), 7(2), 118-132.

Tkach, J. A., Chen, X., Freebairn, L. A., Schmithorst, V. J., Holland, S. K., \& Lewis, B. A. (2011). Neural correlates of phonological processing in speech sound disorder: a functional magnetic resonance imaging study. Brain and Language, 119(1), 42-49.

Wong, W. (2005). Input enhancement: from theory and research to the classroom. Beijing: McGraw-Hill. 
Mi-Jin Kim, et al. • Vocal Rehearsal and Auditory Input Enhancement in SSD

Appendix 1. The item list of the delayed nonword repetition task

\begin{tabular}{ccc}
\hline \multicolumn{3}{c}{ Nonword list } \\
\hline A set & B set & C set \\
\hline 거겡눅 & 너눙닉 & 니버껑 \\
네마똘 & 따깅읃 & 드넨넵 \\
메껭던 & 머겜밍 & 베밍넴 \\
헤능갇 & 후겔둔 & 흐넬맏 \\
거그툰닌 & 니덩멜렙 & 꾸머큰넥 \\
네디뚱겔 & 두넘몽뎅 & 뜨네벤닐 \\
뻬응믄돔 & 떠베띵님 & 무멘기딜 \\
하든고닙 & 후도벵걱 & 버딤네둡 \\
니맙디동닉 & 더기너겡멘 & 기베띰네둡 \\
미듭떼기눌 & 너멜렘두넥 & 두멤네넨받 \\
버님머넨덱 & 버듬벙거텝 & 모트깅메넵 \\
뽀넘므텍뜹 & 삐딤두밍닐 & 뻬드믈레넴 \\
\hline
\end{tabular}




\section{국문초록}

\section{외현적 시연과 청각적 입력 강화가 말소리장애 아동의 지연 비단어 따라말하기 수행력에 미치는 영향 김미진 ${ }^{1}$ 하지완 ${ }^{2}$ \\ ${ }^{1}$ 대구대학교 일반대학원 재활과학과 언어치료전공, ${ }^{2}$ 대구대학교 언어치료학과}

배경 및 목적: 순수 말소리장애 아동(pure SSD), 언어발달지체를 동반한 말소리장애 아동(SSD+LD)과 일반아동(TD)을 대상으로 지 연 비단어 따라말하기 과제를 실시하여, 외현적 시연과 청각적 입력 강화라는 기억 전략이 대상자들의 음운작업기억에 미치는 영향을 알아보고자 하였다. 방법: 3-5세의 pure SSD 18명, SSD+LD 8명, TD 19명을 대상으로 외현적 시연, 청각적 입력 강화, 시연 억제 조건의 지연 비단어 따라말하기 과제를 실시하였다. 자극어는 3 음절, 4 음절, 5 음절로 구성되었고, 자극 제시부터 최종 반응까지 12 초의 지연시 간을 두었다. 실험과제는 $\mathrm{DmDx}$ software를 이용하여 제작하였다. 결과: 첫째, 시연 억제 조건에서 집단 간 차이가 유의하지 않았으나, 외현적 시연 및 청각적 입력 강화 조건에서는 pure SSD와 TD 집단의 수행력이 향상되어 SSD+LD 집단과 유의한 차이를 보였다. 둘째, 오류분석 결과 무반응은 SSD+LD, pure SSD, TD 집단 순으로, 음소대치는 TD, pure SSD, SSD+LD 집단 순으로 유의하게 많이 발생하 였다. 셋째, $\mathrm{SSD}+\mathrm{LD}$ 집단은 나머지 두 집단보다 외현적 시연 시 시연 반응의 변이성을 유의하게 많이 보였다. 논의 및 결론: 외현적 시연 과 청각적 입력 강화는 대상자들의 음운기억 증진에 효과적이나, 이 중 대상자의 부담이 적은 청각적 입력 강화가 보다 효과적이다. pure SSD 집단은 TD 집단만큼 이 두 전략에 의해 음운기억 향상을 기대할 수 있으나, SSD+LD 집단의 경우 그 효과가 제한적이므로 이 를 보완할 수 있는 다른 전략이 강구된다.

핵심어: 말소리장애, 지연 비단어 따라말하기, 음운작업기억, 외현적 시연, 청각적 입력 강화

본 논문은 2017년 정부(교육부)의 재원으로 한국연구재단의 지원을 받아 수행된 연구임(NRF-2017R1C1B1010913).

본 논문은 대구대학교 연구 장학기금 지원에 의한 것임.

\section{참고문헌}

권미선(2004). 베르니케실어증 환자의 실어유형 및 청각언어이해능력의 변화 특성. 이화여자대학교 대학원 박사학위논몬.

김수진, 신지영(2015). 말소리장애. 서울: 시그마프레스.

김영태, 성태제, 이윤경(2003). 취학전 아동의 수용언어 및 표현언어 척도(PRES). 서울: 서울장애인종합복지관.

김영태, 신문자(2004). 우리말조음·음운평가(U-TAP). 서울: 학지사.

김영태, 홍경훈, 김경희, 장혜성, 이주연(2009). 수용·표현어휘력검사(REVT). 서울: 서울장애인종합복지관.

김흥규, 강범모(1997). 한글 사용빈도의 분석. 서울: 고려대학교 민족문화연구소.

류은주, 하지완(2016). 외현적 시연이 단순언어장애아동과 일반아동의 새로운 음운표상인출 수행력에 미치는 영향. Communication Sciences \&

Disorders, 21(4), 605-616.

문선모(1994). 학습방략의 발달과 학업수행. 교육학연구, 32(5), 47-74

이기은, 하지완(2018). 5세와 6세 말소리장애 아동의 음운단기기억과 음운작업기억 능력. Communication Sciences \& Disorders, 23(3), 713-724.

이석정(2015). 6, 7세 아동의 시연조건에 따른 음운단기기억 능력 비교. 대구대학교 대학원 석사학위논문.

이석정, 하지완, 구민모, 황유미, 편성범(2016). 6, 7세 아동의 시연조건에 따른 지연 비단어따라말하기 능력 비교. Communication Sciences \& Disor-

ders, 21(1), 69-83.

조증열, 서상록(2004). 초등학생의 한국어 음운처리 기술과 영어 어휘력 및 어휘학습과의 관계. 외국어교육, 11(1), 179-195.

한은지, 하지완(2017). 말소리장애 아동과 일반 아동의 조음복잡성에 따른 조음변이성 연구. Communication Sciences \& Disorders, 22(4), 772-783.

황민아(2015). 일반아동의 비단어 따라말하기. Communication Sciences \& Disorders, 20(3), 374-385, 


\section{ORCID}

김미진(http://orcid.org/0000-0002-2151-6167); 하지완(http://orcid.org/0000-0002-1191-791X) 